\title{
TRICOLORED BLACKBIRDS FEEDING IN JOSHUA TREE INFLORESCENCES
}

\author{
RYAN S. TERRILL, JAMES M. MALEY, WHITNEY L. E. TSAI, KEVIN B. FISTANIC, \\ ROWDY J. FREELAND, ANNA FRANCESCHELLI, BRYCE LEWIS-SMITH, and \\ LEEZA L. LU, Moore Laboratory of Zoology, Occidental College, Los Angeles, \\ California 90041; ornithoterrill@gmail.com
}

JEREMY B. YODER, Department of Biology, California State University, Northridge, California 91330

The Tricolored Blackbird (Agelaius tricolor) is endangered (Birdlife International 2018) and declining rapidly (Cook and Toft 2005, Meese 2017), designated as threatened by the state of California (Calif. Dept. Fish and Wildlife 2019), and nearly endemic to the California ecoregion (Kelsey 2008). It breeds somewhat nomadically (Hamilton 1998), which behavior has hampered its conservation. For its declining population to be managed, it is essential that the resources on which it depends for food and habitat be understood (Skorupa et al. 1980). Here we describe a previously unknown behavior of the Tricolored Blackbird, foraging in the inflorescences of a common plant.

On 20 April 2019, while on a class field trip, we were driving through the Kelso Valley in Kern County, California, at 1270 m elevation. The habitat was characterized by desert with fairly dense cover of Western Joshua Trees (Yucca brevifolia brevifolia), bordering agricultural fields along the bottom of the valley. We noticed a small flock of blackbirds flying between Joshua Trees and stopped to observe them. We identified them as Tricolored Blackbirds, and saw them probing into the trees' inflorescences (Figure 1). This first flock comprised 11 individuals, with seven or eight females and three or four males. We then noted two other similarly sized flocks engaging in the same behavior. As we observed these birds probing into the inflorescences, they appeared to be obtaining and eating items from among the flowers and developing fruit. They would forage in one tree, probing into and prying open fruits and flowers, then move as a flock to a nearby tree.

Tricolored Blackbirds are opportunistic foragers that take advantage of superabundant resources of diverse nature. They generally eat arthropods, especially insects of the orders Orthoptera and Odonata, but also eat grains and mollusks when available (Crase and DeHaven 1977, Meese 2013, Beedy et al. 2018). They generally forage in open habitats with low vegetation such as grasslands, wetlands, pastures, fields, dairies, and scrub. The only previous description of Tricolored Blackbirds foraging in trees involved the Coast Live Oak, Quercus agrifolia (Wilson et al. 2016).

Many other species of insectivorous birds occur in the southern Sierra Nevada, but we only observed Tricolored Blackbirds foraging in these flowers. The family Icteridae is characterized by an extended postarticular process to the mandible, the site of insertion of the depressor mandibulae muscle (Zusi 1959) and a structure that allows the birds to open the bill with force. This "gaping" behavior allows the Icteridae to obtain food unavailable to other birds, by prying objects open. The ability to pry open inflorescences might mean that the Tricolored Blackbirds have access to the arthropods living in these flowers that other insectivorous birds of other families do not have. If this is true, and a common behavior during periods of extensive Joshua Tree flowering, the inflorescences of Joshua Trees might be important for the foraging of Tricolored Blackbirds. Tricolored Blackbirds occur nearby in the Kern River Valley and occasionally wander in flocks up the Kelso Valley (www.eBird.org, accessed 20 May 2019).

While driving through the Kelso Valley, we noticed that most, if not all, of the Joshua Trees were in flower or fruit. The winter of 2018/2019 was characterized by 


\section{NOTES}

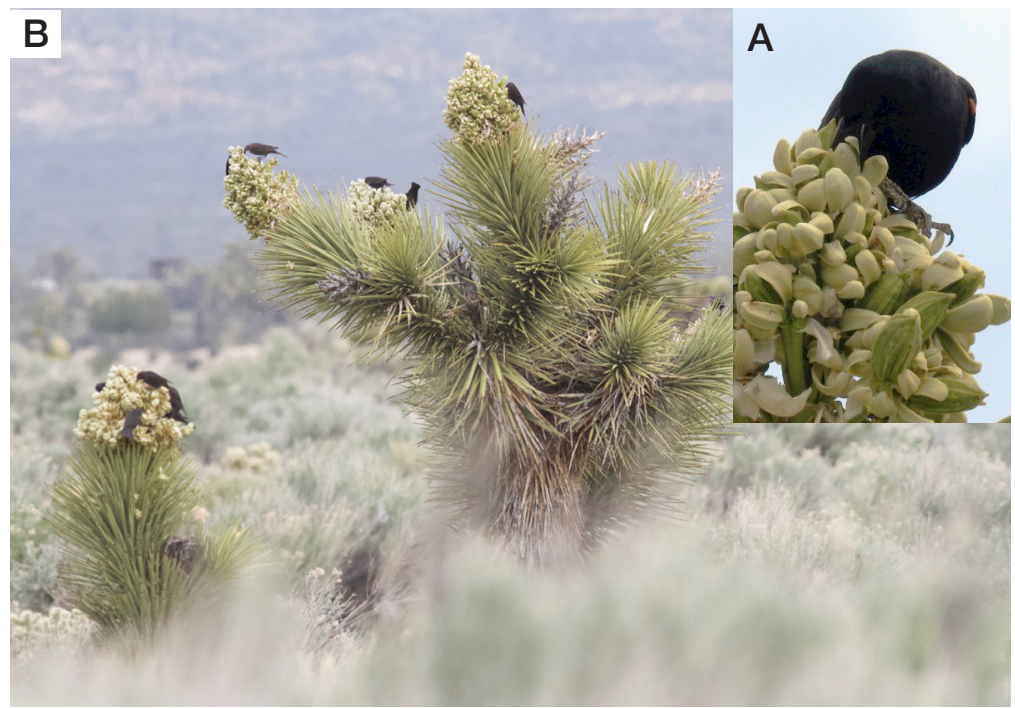

Figure 1. (A) A male Tricolored Blackbird opening an inflorescence of a Joshua Tree by prying into a flower, evidently with the goal of extracting arthropods, including small moths. (B) A small flock of Tricolored Blackbirds foraging in the inflorescences of Joshua Trees in the Kelso Valley, Kern Co., California.

Photos by James M. Maley (A) and Ryan S. Terrill (B)

heavy precipitation, causing a "superbloom" in parts of the California desert (Johnson 2019), which likely contributed to the flowering of these Joshua Trees (Smith et al. 1983). Joshua Tree inflorescences attract a wide variety of arthropods, such as pollinating and nonpollinating yucca moths (genera Tegeticula and Prodoxus, respectively), less specialized taxa including thrips (Thysanoptera), leaf-footed bugs (Coreidae), weevils (Curculionoidea) of the genus Rhinostomus, click beetles (Elateridae), and predators and parasitoids such as lacewings (Neuropterida) and wasps of the genera Eusandalum and Heterospilus (Yoder pers. obs.; Force and Thompson 1984, Pellmyr and Segraves 2003, Pellmyr et al. 2005). At least one photograph appears to show a male Tricolored Blackbird consuming a white moth, most likely Prodoxus sordidus, a nonpollinating yucca moth that lays its eggs in the stalks of flowering Joshua tree inflorescences (Pellmyr et al. 2005). Given that the Tricolored Blackbird is at least somewhat nomadic, this observation suggests that the ephemeral arthropod resources provided by Joshua Trees might be an important source of food for the species in and near the western Mojave Desert where its range overlaps that of the Joshua Tree.

We thank Occidental College for logistical support and vehicle use during this field trip. Jessica Oswald Terrill and John E. McCormack provided helpful support and review of the manuscript. We thank reviewers Daniel A. Airola and Edward C. Beedy for helpful comments on this paper and Daniel D. Gibson for providing useful edits.

\section{LITERATURE CITED}

Beedy, E. C., Hamilton, W. J. III, Meese, R. J., Airola, D. A., and Pyle, P. 2018. Tricolored Blackbird (Agelaius tricolor), version 3.1, in The Birds of North America 


\section{NOTES}

(P. G. Rodewald, ed.). Cornell Lab Ornithol., Ithaca, NY; doi 10.2173/bna. tribla.03.1.

BirdLife International 2018. Agelaius tricolor. The IUCN Red List of Threatened Species 2018:e.T22724196A132028149; http://dx.doi.org/10.2305/IUCN. UK.2018-2.RLTS.T22724196A132028149.en (downloaded 20 May 2019).

California Department of Fish and Wildlife. 2019. State and federally listed and threatened animals of California: April 23, 2019; https://nrm.dfg.ca.gov/FileHandler. ashx?DocumentID=109405.

Cook, L. F., and Toft, C. A. 2005. Dynamics of extinction: Population decline in the colonially nesting Tricolored Blackbird Agelaius tricolor. Bird Cons. Int. 15:73-88; doi 10.1017/S0959270905000067.

Crase, F. T., and DeHaven, R. W. 1977. Food of nestling Tricolored Blackbirds. Condor 79:265-269; doi 10.2307/1367173.

Force, D. C., and Thompson, M. L. 1984. Parasitoids of the immature stages of several southwestern yucca moths. Southwest. Nat. 29:45-56; doi 10.2307/3670768.

Hamilton, W. J. III. 1998. Tricolored Blackbird itinerant breeding in California. Condor 100:218-226; doi 10.2307/1370263.

Johnson, L. A. 2019. Seeing California's super bloom from space. Colo. Rev. 46:126; doi $10.1353 /$ col.2019.0024.

Kelsey, R. 2008. Results of the Tricolored Blackbird 2008 census. Report to U.S. Fish \& Wildlife Service, Portland, OR.

Meese, R. J. 2013. Chronic low reproductive success of the colonial Tricolored Blackbird from 2006 to 2011. W. Birds 44:98-113.

Meese, R. J. 2017. Results of the 2017 Tricolored Blackbird Statewide Survey. Calif. Dept. Fish and Wildlife, Wildlife Branch, Nongame Wildlife Program Report 2017-04; https://nrm.dfg.ca.gov/FileHandler.ashx?DocumentID=151160.

Pellmyr, O., and Segraves, K. A. 2003. Pollinator divergence within an obligate pollination mutualism: Two yucca moth species (Lepidoptera; Prodoxidae: Tegeticula) on the Joshua tree (Yucca brevifolia; Agavaceae). Ann. Entomol. Soc. Am. 96:716-722; doi 10.1603/0013-8746(2003)096[0716:PDWAOM]2.0.CO;2.

Pellmyr, O., Balcázar-Lara, M., Althoff, D. M., Segraves, K. A., and Leebens-Mack, J. 2005. Phylogeny and life-history evolution of Prodoxus yucca moths. Syst. Entomol. 31:1-20; doi 10.1111/j.1365-3113.2005.00301.x.

Skorupa, J. P., Hothem, R. L., and DeHaven, R. W. 1980. Foods of breeding Tricolored Blackbirds in agricultural areas of Merced County, California. Condor 82:465-467; doi 10.2307/1367578.

Smith, S. D., Hartsock, T. L., and Nobel, P. S. 1983. Ecophysiology of Yucca brevifolia, an arborescent monocot of the Mojave Desert. Oecologia 60:1017; doi:10.1007/bf00379313.

Wilson, C. R., Meese, R. J., and Wyckoff, A. C. 2016. Breeding chronology, movements, and life history observations of Tricolored Blackbirds in the California central coast. Calif. Fish and Game 102:162-174.

Zusi, R. L. 1959. The function of the depressor mandibulae muscle in certain passerine birds. Auk 76:537-539; doi 10.2307/4082331.

Accepted 20 May 2019 